OPEN ACCESS

Edited by:

Fu Zhao,

Purdue University, United States

Reviewed by:

Hongyue Jin

University of Arizona, United States

Xiangyun Gao,

China University of Geosciences,

China

*Correspondence:

Brett Zeuner

bzeuner@umich.edu

Specialty section:

This article was submitted to

Energy Systems and Policy,

a section of the journal

Frontiers in Energy Research

Received: 01 August 2018

Accepted: 30 October 2018

Published: 21 November 2018

Citation:

Zeuner B (2018) An Obsolescing

Bargain in a Rentier State: Multinationals, Artisanal Miners, and Cobalt in the Democratic Republic of

Congo. Front. Energy Res. 6:123.

doi: 10.3389/fenrg.2018.00123

\section{An Obsolescing Bargain in a Rentier State: Multinationals, Artisanal Miners, and Cobalt in the Democratic Republic of Congo}

\author{
Brett Zeuner* \\ School for Environment and Sustainability, University of Michigan, Ann Arbor, MI, United States
}

Drawing from theories on the political-economy of natural resources, this paper broadens the discussion surrounding cobalt sourced from the former Katanga region of the Democratic Republic of Congo; specifically, the use of that cobalt in rechargeable lithium-ion batteries as energy storage in electrified transportation and distributed energy systems. Two theories, Rentier State, and Obsolescing Bargaining, are applied to the cases of multinational and artisanal cobalt mining operations in the former Katanga region. Risks between the DRC government and multinational cobalt mining companies are compared to the risks present in artisanal cobalt mining. This paper explores how the decision to include or exclude Congolese, artisanal cobalt from supply chains involves broader questions of bargaining power, political stability, and resource dependency. This paper expands consideration to explore how the inclusion of artisanal cobalt in the supply chain might impact political stability and corruption in the DRC, rather than focusing on how Western or Chinese purchasers of electrified vehicles, for example, might perceive the suitability of the product's supply chain. By relating artisanal cobalt mining to multinational mining companies and the broader political issues present in the DRC, decision-makers can better consider current and historical outcomes as part of a broader political-economy that includes both artisanal and multinational mining. Furthermore, this paper hopes to provide a robust argument for the transparent and intentional inclusion of artisanal cobalt in electrified vehicle supply chains to make the transition to lowcarbon transportation more sustainable through improvements to measures of social sustainability in the DRC.

\begin{abstract}
Keywords: DRC, rentier state, obsolescing bargain, cobalt, ASM, electric vehicle, responsible sourcing, political economy
\end{abstract}

\section{INTRODUCTION}

As discourse grows regarding the question of whether to include or exclude artisanal cobalt from electrified transportation supply chains, media coverage addressing such concerns has largely left out cross-comparisons between large-scale, multinational, and small-scale, artisanal cobalt mining operations. 
With countries from China to Norway adopting electrification mandates for transportation systems, the demand for cobalt has been expected to grow dramatically ${ }^{1,2}$. Most electrified vehicles, for example, use lithium-ion batteries to store the energy needed to put the car in motion ${ }^{3}$. These batteries are relevant to the cobalt supply chain due to cobalt's usefulness in providing a structural layer for lithium ions to move through as they shrink and expand with each charge and discharge ${ }^{4}$. Cobalt is desired for this use due to its extreme resilience and heat-resistant qualities, extending the range, and life of the battery system ${ }^{5}$.

The relationship of this useful metal to the Democratic Republic of Congo is one of geographic distribution. With more than half of the estimated 110,000 metric tons of cobalt extracted globally in 2017 being of DRC-origin, it is likely that the use of cobalt in future electrified vehicles will continue to include Congolese cobalt. This assumption is also supported by the fact that the DRC has the world's largest proportion of global reserves, accounting for approximately $50 \%$ of global proved-reserves. While other relevant factors that may affect the relationship of cobalt and energy storage are discussed later, it is reasoned that any large-scale adoption of distributed energy and/or electrified transportation systems will rely, at least in part, on cobalt from the DRC to meet production goals.

Regarding the source of this cobalt in the DRC, estimates state that the majority is produced by large-scale mining operations, run by multinational companies and the state-owned Gecamines $^{6}$. There is concern, though, regarding a significant proportion of cobalt mined in the DRC originates from smallscale, hand-mined sources, referred to as artisanal, small-scale mining, or ASM. According to Amnesty International, a global non-governmental organization focused on human rights, the Congolese government has confirmed estimates that roughly $20 \%$ of the cobalt currently exported from the country is of ASM origin ${ }^{7}$. Studies done by Belgian geologists estimated that as much as $60 \%$ of the DRC's cobalt exports were sourced through ASM in $2011^{8}$. This method of mining has also been linked to human rights violations, predominantly issues of child labor and worker exploitation (Banza et al., 2009; Geenen, 2012; Narendrula et al., 2012; de Haan and Geenen, 2016; Faber et al., 2017; Hilhorst and Wakenge, 2017; Banza Lubaba Nkulu et al., $2018)^{7}$.

Beginning in 2017, further attention was brought to the issue of corporate compliance within the automotive industry related to cobalt sourcing and global standards of due diligence common with other previously regulated, technology-relevant metals, including 3TG (Tungsten, Tantalum, Tin, and Gold) ${ }^{9}$.

\footnotetext{
${ }^{1}$ https://www.bcg.com/d/press/2november2017-electrified-vehicles-take-half-ofglobal-auto-market- 175464

${ }^{2}$ https://www.weforum.org/agenda/2017/09/lithium-ion-batteries-ethics-globalbattery-alliance/

${ }^{3}$ https://www.afdc.energy.gov/vehicles/electric_batteries.html

${ }^{4}$ https://www.weforum.org/agenda/2017/09/lithium-ion-batteries-ethics-globalbattery-alliance/

${ }^{5}$ https://minerals.usgs.gov/minerals/pubs/commodity/cobalt/mcs-2018-cobal.pdf

${ }^{6} \mathrm{https} / / / \mathrm{minerals}$.usgs.gov/minerals/pubs/commodity/cobalt/cobalt-supplysecurity.pdf

${ }^{7}$ https://www.es.amnesty.org/uploads/media/Time_to_recharge_online_1411.pdf ${ }^{8}$ https://www.oeko.de/oekodoc/1294/2011-419-en.pdf

${ }^{9} \mathrm{http}: / /$ www.responsiblebusiness.org/news-and-events/news/ai2017/
}

In Spring 2018, news outlets, like CNN and CBS News, also covered the topic of artisanal cobalt from the DRC, with a focus on child labor in the supply chain of electrified vehicles ${ }^{10,11}$. For this reason, electric vehicles will be the main industry considered here as their adoption represents initiatives in both low-carbon energy and transportation system reforms.

Absent from the reporting of such news groups and NGOs, though, was the framing of electrified vehicles within broader political-economic and energy justice frameworks, including the emphasis on relevant historical context and recent developments in bargaining power. Further, discussions in media around ASM cobalt in the electrified vehicle supply chain take place separate from discussions about large-scale, mechanized mining commonly done by multinational companies. To address this, discourse on cobalt and the electrified vehicle supply chain must address the socio-political issues inherent to non-ASM cobalt extraction that relies solely on partnerships between multinational and state-owned corporate actors. This paper argues that such partnerships actually exacerbate socio-political risks through the reinforcement of authoritarian governments and their financial autonomy from the citizenry.

\section{BACKGROUND}

\section{Cobalt as an Obsolescing Bargain}

The Obsolescing Bargaining Theory, developed by Raymond Vernon in the 1970s, posits that the power dynamics of the relationship between resource-heavy governments and multinational corporations in the extractives industry will shift over time in the government's favor (Ostrowski, 2013; p. 104105). The original theory, and recent applications of it, focus on the relationship between oil-consuming and oil-producing countries (Ostrowski, 2013; p. 104-105; Bayulgen, 2010). Unlike oil, where one country does not hold a majority of the world's resource, the DRC maintains a majority of the world's production and reserves of cobalt ${ }^{12}$. This section explores the application of this theory to the DRC, cobalt, and electrified vehicles, a topic that was not found in the literature review. Despite this, references to leveraging power and the risk of dependency on the DRC for cobalt have been discussed by the US intelligence community for decades, including a recent distinction of cobalt as a critical mineral (Ngolet, 2000) ${ }^{13,14}$.

One of the first explicit references to cobalt and the balance of power between consuming countries like the United States and the cobalt-rich DRC occurred after the 1978 conflict known as Shaba II. This conflict involved the rebel group FLNC, or Front for the National Liberation of Congo, who sought to overthrow then-President Mobutu and install an independent socialist

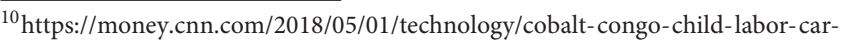
smartphone-batteries/index.html

${ }^{11}$ https://www.cbsnews.com/news/children-cobalt-mining-congo-cbsnewsinvestigation-ziki-swaze/

${ }^{12} \mathrm{https} / /$ minerals.usgs.gov/minerals/pubs/commodity/cobalt/mcs-2018-cobal. pdf

${ }^{13} \mathrm{https} / / /$ www.cia.gov/library/readingroom/docs/CIA-

RDP83B00851R000100040001-1.pdf

${ }^{14}$ https://www.federalregister.gov/documents/2018/05/18/2018-10667/final-listof-critical-minerals-2018
} 
country (Nzongola-Natalaja, 2002; Kisangani, 2012). The FLNC successfully seized critical copper and cobalt mines in Kolwezi to critically disrupt the supply of these strategic substances that the governments of, both, Western powers and Mobutu relied on for military applications and funding, respectively (Kisangani, 2012) $)^{15}$.

At the time, cobalt was the country's number-two export and accounted for over US $\$ 347$ million at the time ${ }^{16}$. According to the same source, cobalt prices jumped $24 \%$ following the attack. This disruption triggered multiple industries, including aerospace, superalloys, and magnets, to begin researching the substitutability of the metal according to a report by the US Central Intelligence Agency regarding the West's dependence and vulnerability to Shaba's share of cobalt mineral resources ${ }^{17}$. That same report stated that within two years of Shaba II, the use of cobalt in US-made magnets dropped 50\% while the domestic recycling rate of cobalt more than tripled to just under $10 \%$. Additionally, the DRC government recognized the risk of substitution of cobalt in products if the country did not help keep prices low ${ }^{18}$.

By 2017, power dynamics seemed to shift in favor of the DRC as the average price of cobalt doubled over the year ${ }^{19}$. Prior increases in demand and output were not always met with increased valuation ${ }^{20}$. This developing shift in bargaining power was further evinced by the country's 2018 revisions to its mining code, changing the royalty structures, among other provisions, which supports the main idea behind Vernon's theory. The changes increased royalties for companies on mined cobalt from two percent to ten percent via a recategorization of the metal as a "strategic substance" 21 . The revised code also included a provision that would enable the country to increase the taxation of any company's excess mining profits to 50 percent when the commodity price stated in a company's feasibility study increases by 25 percent or more ${ }^{22}$. Another major change was the requirement that all ore be refined domestically, setting limitations on the exportation of raw ore ${ }^{23}$. These changes were contested by the mining industry, including threats of legal action from multinational companies like Glencore and Randgold ${ }^{24}$. However, after a

\footnotetext{
${ }^{15}$ https://www.armyupress.army.mil/Portals/7/combat-studies-institute/ csibooks/ShabaII_FrenchBelgianIntervention_Odom.pdf

${ }^{16}$ https://www.nytimes.com/1981/08/30/weekinreview/zaire-s-bloody-pastmakes-cobalt-s-future-uncertain.html

${ }^{17}$ https://www.cia.gov/library/readingroom/docs/CIARDP83B00851R000100040001-1.pdf

${ }^{18}$ https://www.nytimes.com/1981/08/30/weekinreview/zaire-s-bloody-pastmakes-cobalt-s-future-uncertain.html

${ }^{19}$ https://phys.org/news/2018-02-electric-car-jumpstarts-cobalt-prices.html

${ }^{20} \mathrm{https}$ ///www.washingtonpost.com/graphics/business/batteries/congo-cobaltmining-for-lithium-ion-battery/

${ }^{21}$ https://politicsofpoverty.oxfamamerica.org/2018/04/understanding-drcs-newmining-law-power-play-will-the-congolese-people-benefit/

${ }^{22}$ http://congomines.org/system/attachments/assets/000/001/467/original/J.O. _n\%C2\%B0_spe\%C3\%ACcial_du_28_mars_2018_CODE_MINIER.PDF.pdf? 1523182711

${ }^{23}$ https://www.dlapiper.com/en/morocco/insights/publications/2018/08/

democratic-republic-of-congo-mining-code/

${ }^{24}$ https://www.miningreview.com/new-drc-mining-code-effect-still-causeconcern/
}

6-h meeting with Kabila, which the DRC President postponed 24 hours, the companies were informed that the code would be signed with changes determined on a case-by-case basis; prompting concerns of corruption from non-governmental organizations $^{25}$.

\section{Rentier State Theory}

Rentier State Theory is a political-economic theory that argues resource-rich countries who are economically dependent on concessions paid for natural resource rights are more likely to be financially autonomous from their citizenry. This financial autonomy is reasoned to yield more authoritarian forms of governance (Omeje, 2008; Ostrowski, 2013; p. 106;). Explained another way, the state is not financially dependent on its citizenry through taxation, for example. This theory assumes that governments respond to citizen concerns, at least in part, through positive changes to taxation policies. Ostrowski identifies several rentier theorists who argue that taxation acts as a motivating force for governments to be more accountable to their people (Ostrowski, 2013; p. 106). This is relevant to the DRC as the country relies on the extractive sector for approximately $25-28 \%$ of government revenues, of which mining accounts for $74-82 \%$ (Lezhnev, 2016) ${ }^{26}$. At the same time, the country ranked 176 out of 187 on the United Nations Human Development Index ${ }^{27}$. These social conditions are compounded by political insecurity, as well (Omeje, 2008; Peyer et al., 2014; Banza Lubaba Nkulu et al., 2018) 28,29 .

\section{Distinguishing Artisanal Mining From Multinational, Industrial Operations Within the Two Theoretical Frameworks}

In the case of cobalt mining in the DRC, distinction must be made between multinationally-owned, large-scale mining operations and small-scale, hand-mined operations, referred to as artisanal, small-scale mining or ASM. Official estimates state that the majority of cobalt is produced by large-scale mining operations, run by multinational companies and the state-owned Gecamines ${ }^{30}$. However, ASM provides subsistence for those struggling with access to adequate food, water, and housing (de Haan and Eichstaedt, 2011; Geenen, 2012; Faber et al., 2017; Banza Lubaba Nkulu et al., 2018).

Artisanal miners, or creuseurs, as they are known locally, are relevant to the theories of Rentier State and Obsolescing Bargaining as they represent both citizens and mineral producers. However, unlike multinational mining companies who purchase mineral concessions, creuseurs are typically mining for subsistence and lack the resources necessary to engage in mining as a landowning entity (Geenen, 2012; de Haan and

\footnotetext{
${ }^{25} \mathrm{https} / /$ politicsofpoverty.oxfamamerica.org/2018/04/understanding-drcs-newmining-law-power-play-will-the- congolese-people-benefit/

${ }^{26} \mathrm{https}$ ://eiti.org/democratic-republic- of-congo\#contribution-of-the- extractiveindustry-to-the-economy

${ }^{27} \mathrm{http}: / /$ www.worldbank.org/en/country/drc/overview

${ }^{28} \mathrm{https} / /$ usun.state.gov/highlights/8300

${ }^{29} \mathrm{https} / / /$ usun.state.gov/remarks/8533

${ }^{30} \mathrm{https} / /$ minerals.usgs.gov/minerals/pubs/commodity/cobalt/cobalt-supplysecurity.pdf
} 
Geenen, 2016; Faber et al., 2017; Hilhorst and Wakenge, 2017; Banza Lubaba Nkulu et al., 2018). Revisions to the mining code in 2018 further restricted artisanal miners from owning land by barring natural persons from owning mineral rights, thus making mineral concessions possible only between legallyrecognized groups and the state; in addition, the revisions required that artisanal miners be of Congolese nationality ${ }^{31}$. The provision requiring artisanal miners to mine only in zones explicitly designated for artisanal mining was not changed. In relation to rentier state, the creuseurs do not pay the newly revised rent or royalties to the state but instead pay a flat value added tax rate. The increased taxation, resulting from the recent code update on strategic substances like cobalt, is passed on to the purchasers of the artisanal cobalt who buy cobalt ore in depots, or open-air markets; representing mostly Chinese companies $^{32}$.

Regarding the bargaining power of creuseurs, there have been numerous examples of exploitation by state and corporate actors which suggests a low-to-zero level of bargaining power on the part of artisanal miners (Geenen, 2012; de Haan and Geenen, 2016; Faber et al., 2017; Hilhorst and Wakenge, 2017; Banza Lubaba Nkulu et al., 2018). In addition to exploitation, bargaining power is further reduced through the requirement to mine in only those zones designated by the government for ASM activity.

\section{Glencore, PLC as a Case Study of Obsolescing Bargaining in a Rentier State}

Glencore operates two cobalt-producing mines in the DRC through its subsidiary Katanga Mining Limited (KML). ${ }^{33}$ KML currently has ownership of two cobalt-producing sites, Kamoto and Mutanda, that were created as joint ventures between the multinational mining company and the stateowned Gecamines. Glencore has since acquired 86\% ownership of the Kamoto concessions and full ownership of Mutanda assets through purchases of stakes from Gecamines and the recently US-sanctioned Dan Gertler. Gertler was sanctioned by the United States Department of Treasury in December 2017 for using "his close friendship with DRC President Joseph Kabila to act as a middleman for mining asset sales in the DRC, requiring some multinational companies to go through Gertler to do business with the Congolese state". 34,35

During this time, Gertler and another associate had filed lawsuits in DRC courts against Glencore, accusing the company of improper compensation ${ }^{36}$. Glencore settled with Gertler in DRC courts and agreed to make payments despite US sanctions citing the payments as "the only viable option to avoid the

\footnotetext{
${ }^{31}$ http://congomines.org/system/attachments/assets/000/001/467/original/J.O. _n\%C2\%B0_spe\%C3\%ACcial_du_28_mars_2018_CODE_MINIER.PDF.pdf? 1523182711

${ }^{32}$ https://www.washingtonpost.com/graphics/business/batteries/congo-cobaltmining-for-lithium-ion-battery/

${ }^{33}$ http://www.glencore.com

${ }^{34}$ https://home.treasury.gov/news/press-releases/sm0243

${ }^{35} \mathrm{https} / / /$ home.treasury.gov/news/press-releases/sm0417

${ }^{36} \mathrm{http}: / / \mathrm{www}$.mining.com/glencore-faces-third-congo-legal-challenge-year/
}

material risk of seizure" of the Kamoto and Mutanda mines ${ }^{37}$. The multinational mining company was then subpoeanaed by the US government for corruption allegations ${ }^{38}$. Then, in a final blow, Glencore was forced to take part in a US\$ 5.6 billion debtfor-equity swap with the DRC government to maintain its control over its Kamoto and Mutanda assets ${ }^{39}$.

When questioning why the bargaining power of a mining company that contributed over US\$ 1 billion over the last three years could obsolesce, one must consider the global landscape of cobalt mining and production. As discussed earlier, the DRC accounts for the majority of the world's cobalt reserves and current production. For Glencore to be the world's top cobalt producer, it must do business in the DRC. Considering how this relates to the concept of obsolescing bargains, one might reason that the bargaining power of a multinational company would be higher if there were other nation states with comparable or greater reserves of the resource of interest. This is simply not the case for cobalt.

In the case of Glencore and cobalt mining in the DRC, the country's political leaders had an opportunity to take advantage of the obsolescing of the multinational cobalt mining industry's bargaining power. This lucrative opportunity supports, rather than contradicts, their reliance on industry for government revenue. DRC government can capitalize on its legal system and jurisdiction to dissolve contracts, revise regulations, or otherwise influence legal disputes in domestic courts with the state having primacy over corporate claims (Omeje, 2008; p. 141). Furthermore, Glencore's historical investments in the area seem to complicate the company's ability to easily shift assets, evinced by the willingness to potentially violate US sanctions and to engage in a multi-billion-dollar debt-for-equity swap.

\section{DISCUSSION}

As explained in the Rentier State and Obsolescing Bargain theories, political leaders of resource-dependent countries are more reliant on industry than their own people for the financing of the government. In the case of the DRC, a reliance on the cobalt industry for tax revenue represents a type of mutualistic relationship where multinational companies and the Congolese State benefit one another. This relationship is currently shifting as changes to the country's mining code reflect a weakening, or obsolescing, of multinational mining companies' bargaining power.

The implications of these theoretical arguments are related to future energy infrastructure as an increase in demand for rechargeable batteries, and the energy and transportation systems they power, would require increased amounts of cobalt assuming that the metal is not completely substituted out of energy storage technologies. It follows that as demand for cobalt increases, due

\footnotetext{
${ }^{37}$ https://www.bloomberg.com/news/articles/2018-06-15/glencore-to-restartpayments-to-sanctioned-billionaire-gertler

${ }^{38}$ https://www.occrp.org/en/27-ccwatch/cc-watch-briefs/8285-us-subpoenasglencore-over-alleged-corruption

${ }^{39}$ https://www.ft.com/content/eb73096e-6e6c-11e8-92d3-6c13e5c92914
} 
to an increased demand for products like electrified vehicles, the bargaining power of the Congolese State also increases. This would occur as the country holds the majority of global reserves and mining companies seek to remain in business to satisfy the demand. Another point to consider is the driving force of carbon mitigation strategies to the increasing demand of distributed energy systems and electrified vehicles, and the chain reaction this might have on the power dynamics discussed here.

While creating negative media attention for automakers, artisanal small-scale mining, or ASM, has been viewed as an opportunity by some manufacturers, like Daimler, who want to utilize technological solutions "to combat the social and environmental risks in the cobalt value chain" ${ }^{40}$. These solutions do not suggest excluding ASM-sourced cobalt from the electrified vehicle supply chain. Rather, they suggest that ASM-sourced cobalt will play a role in the future supply chains of the lowto-zero carbon vehicles. It is argued here that ASM-sourced cobalt could help address the interdependency between mining companies and the DRC government, which in turn addresses the tendency for the country to engage in corruption and authoritarianism.

This suggests that increasing the share of ASM-cobalt from the DRC would represent a shift in the foundation of Rentier State Theory. Shifting more cobalt mining to ASM and reducing the number and influence of large mining companies would, in theory, address the issue of financial autonomy by making the government more reliant on mining communities for tax revenue. Artisanal miners, unlike multinational mining companies, represent domestic interests. Thus, it is reasoned that if a larger proportion of cobalt is sourced through ASM, then the government would be more likely to make decisions in the interest of those who are represented by the collectives to ensure that production, and the resulting tax revenue, remain strong. ASM has also shown some promise for establishing local solidarity and improving equity (Bryceson and Fisher, 2014).

Given that all ASM must be done through cooperatives following President Kabila's 2010 ban and subsequent reinstatement in 2011, it is understood that this theorized increase of ASM would involve mining cooperatives (Geenen, 2012). The question then becomes whether the establishment of ASM collectives could legitimize ASM communities to disrupt the bargaining power dynamic between multinational mining companies and the state. As Geenen has pointed out, though, top-down organization of ASM mining cooperatives has been mostly ineffective (2012). Thus, the distinction must be made between top-down formalizations of the ASM sector and bottom-up organization when discussing benefits from such collectives.

Another point to consider, though, is whether ASM collectives would be subjected to the same obsolesce of bargaining power that was pointed out for mining companies. It is reasoned that this would not be the case since the miners themselves are citizens and are embedded within their communities. Additionally, if

\footnotetext{
${ }^{40}$ https://www.reuters.com/article/us-daimler-cobalt/daimler-joins-chinasresponsible-cobalt-initiative-idUSKBN1HW1EQ
}

support was gained from non-mining multinationals who rely on consistent supplies of cobalt for their final products, such as electric vehicle manufacturers, then ASM collectives could potentially transition into more formalized mining operations that are made up of citizens but financed by non-mining multinationals. Said another way, if trust was built between non-mining multinationals and ASM collectives that were previously operating in designated zones, the former could finance the purchase of the zone's mineral concessions to make the collective more profitable to the state by opening these areas up to the higher taxes placed on formalized mining. One could argue that such a concept would create "enclaves of security" that are insulated or otherwise socially removed from the suffering of citizens living outside of the ASM communities. This counter-argument is flawed, though, as it does not consider that such "enclaves of security" are already created and reinforced by multinational mining companies (Ostrowski, 2013; p. 94).

\section{ADDITIONAL CONSIDERATIONS AND CONCLUSION}

These considerations reveal the often-attenuated linkage between consumer choices in wealthier cities and countries and the tangible impacts to communities where natural resources necessary for such products are sourced. Regarding the sustainability of a transition to low-carbon, distributed energy and transportation systems, social risks must be considered alongside environmental gains, such as reductions in nations' carbon footprints. If the planet must reduce carbon emissions to avoid climate risks in the future, what sacrifices are willing to be made in this transition? More importantly, what are the justice implications of such transitions and how can transitional justice be realized in the electrification of vehicles in the twenty-first century? If cobalt can be substituted, what are the potential social impacts to ASMdependent creseurs in the DRC from such a technological shift?

As argued in this paper, the extraction of cobalt through partnerships between multi-national mining companies and the government reinforces political instability and corruption. This is significant as it relates to the incidence of future conflict and the proliferation of artisanal cobalt mining. While artisanal cobalt mining has been linked to negative health outcomes, such as increased risk of exposure to uranium and even death, it also provides subsistence for those struggling with access to adequate food, water, and housing (Banza et al., 2009; de Haan and Eichstaedt, 2011; Geenen, 2012; Narendrula et al., 2012; Faber et al., 2017; Hilhorst and Wakenge, 2017; Banza Lubaba Nkulu et al., 2018). Considering what a just transition for artisanal cobalt mine workers would look like involves the necessary identification of solutions to the broader issues that create such situations; where the laborers' lives are dependent on a job that is subsequently reducing their quality of life. What is not argued in this paper is that a shift toward more artisanal cobalt would come without risk. Ongoing efforts to address 
risks in artisanal mining should continue alongside further research to examine how multinational mining companies contribute to current realities for mining communities in the DRC.

\section{REFERENCES}

Banza Lubaba Nkulu, C., Casas, L., Haufroid, V., De Putter, T., Saenen, N. D., Kayembe-Kitenge, T., et al. (2018). Sustainability of artisanal mining of cobalt in DR Congo. Nature sustainability 1:495. doi: 10.1038/s41893-018-0139-4

Banza, C. L. N., Nawrot, T. S., Haufroid, V., Decrée, S., De Putter, T., Smolders, E., et al. (2009). High human exposure to cobalt and other metals in Katanga, a mining area of the Democratic Republic of Congo. Environ. Res. 109, 745-752. doi: 10.1016/j.envres.2009.04.012

Bayulgen, O. (2010). Foreign Investment and Political Regimes: The Oil Sector in Azerbaijan, Russia, and Norway. New York, NY: Cambridge University Press.

Bryceson, D., and Fisher, E. (2014). "Artisanal mining's democratizing directions and deviations," in Mining and Social Transformation in Africa: Mineralizing and Democratizing Trends in Artisanal Production, eds D. Bryceson, E. Fisher, J. B. Jønsson, and R. Mwaipopo (Abingdon: Routledge), 181-209.

de Haan, J., and Geenen, S. (2016). Mining cooperatives in Eastern DRC: the interplay between historical power relations and formal institutions. Extractive Indus. Soc. 3, 823-831. doi: 10.1016/j.exis.2016.05.003

Eichstaedt, P. (2011). Consuming the Congo: War and Conflict Minerals in the World's Deadliest Place. Chicago, IL: Lawrence Hill Books.

Faber, B., Krause, B., and Sánchez De La Sierra, R., (2017). Artisanal Mining, Livelihoods, and Child Labor in the Cobalt Supply Chain of the Democratic Republic of Congo. Center for Effective Global Action Policy Report. Berkeley, CA: University of California CEGA. Available online at: https://escholarship. org/uc/item/17m9g4wm

Geenen, S. (2012). A dangerous bet: the challenges of formalizing artisanal mining in the Democratic Republic of Congo. Resour. Policy 37, 322-330. doi: 10.1016/j.resourpol.2012.02.004

Hilhorst, D., and Wakenge, C. I. (2017). "Emergency or durable solution? Coltan mining and cooperatives in northern Katanga (DRC)," in People, Aid and Institutions in Socio-Economic Recovery?: Facing Fragilities, eds D. Hilhorst, B. Weijs, and G. van der Haar (London, UK: Routledge), 82-98.

Kisangani, E. (2012). Civil Wars in the Democratic Republic of Congo, 1960 - 2010. Boulder, CO: Lynne Rienner Publishers.

\section{AUTHOR CONTRIBUTIONS}

The author confirms being the sole contributor of this work and has approved it for publication.

Lezhnev, S. (2016). A Criminal State. Understanding and Countering Institutionalized Corruption and Violence in the Democratic Republic of Congo. Enough Project Violent Kleptocracy Series. East \& Central Africa.

Narendrula, R., Nkongolo, K. K., and Beckett, P. (2012). Comparative soil metal analyses in sudbury (Ontario, Canada) and lubumbashi (Katanga, DRCongo). Bull. Environ. Contamin. Toxicol. 88, 187-192. doi: 10.1007/s00128-01 1-0485-7

Ngolet, F. (2000). African and American Connivance in Congo-Zaire. Africa Today 47:64. doi: 10.2979/AFT.2000.47.1.64

Nzongola-Natalaja, G. (2002). The Congo: From Leopold to Kabila. New York, NY: Zed Books.

Omeje, K. D, (Ed). (2008). Extractive Economies and Conflicts in the Global South: Multi-Regional Perspectives On Rentier Politics. Ashgate Publishing, Ltd.

Ostrowski, W. (2013). “The political economy of global resources," in Global Resources, eds R. Dannreuther and W. Ostrowski (London, UK: Palgrave Macmillan), 98-115.

Peyer, C., Feeney, P., and Mercier, F. (2014). PR or Progress? Glencore's Corporate Responsibility in the Democratic Republic of the Congo. Rights and Accountability in Development (RAID). Ävailable online at: http://www.raiduk.org/sites/default/files/glencore-report-June2014.pdf (Accessed: October 4, 2015)

Conflict of Interest Statement: The author declares that the research was conducted in the absence of any commercial or financial relationships that could be construed as a potential conflict of interest.

Copyright () 2018 Zeuner. This is an open-access article distributed under the terms of the Creative Commons Attribution License (CC BY). The use, distribution or reproduction in other forums is permitted, provided the original author(s) and the copyright owner(s) are credited and that the original publication in this journal is cited, in accordance with accepted academic practice. No use, distribution or reproduction is permitted which does not comply with these terms. 